Article

\title{
The Relationship between Renewable Energy and Human Development in OECD Countries: A Panel Data Analysis
}

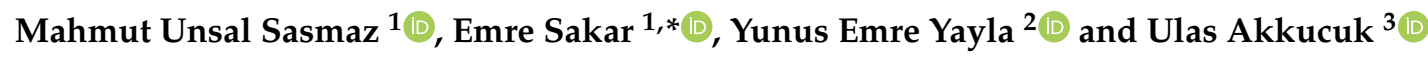 \\ 1 Department of Public Finance, Faculty of Economics and Administrative Sciences, Usak University, \\ Usak 64000, Turkey; mahmut.sasmaz@usak.edu.tr \\ 2 Department of Public Finance, Social Sciences Institute, Afyon Kocatepe University, \\ Afyonkarahisar 03000, Turkey; yunusyay89@gmail.com \\ 3 Department of Management, Faculty of Economics and Administrative Sciences, Bogazici University, \\ Istanbul 34342, Turkey; ulas.akkucuk@boun.edu.tr \\ * Correspondence: emre.sakar@usak.edu.tr
}

Received: 15 August 2020; Accepted: 8 September 2020; Published: 10 September 2020

\begin{abstract}
Renewable energy has attracted researcher attention in recent years, and the number of studies conducted on the topic has increased. The importance of renewable energy has increased because certain energy resources are exhaustible and they damage the environment in various ways. Fossil fuel-based energy is the main culprit for environmental damage and lately renewable energy is the main focus as a safe alternative to fossil fuels. However, replacement of fossil fuels by renewables may have a negative impact on human development, even if it has a positive impact on the environment. With this rationale, this study investigates the relationship between renewable energy and human development in 28 OECD (Organization for Economic Cooperation and Development) countries from 1990 to 2017 by using the Westerlund and Edgerton panel cointegration test with structural breaks and the Dumitrescu and Hurlin causality test. The results of the panel data analysis revealed that renewable energy affected human development positively. In addition, the causality test determined the presence of a bidirectional causality relationship between renewable energy and human development. This study is unique in the sense that it is the only study in the literature examining the relationship between human development index and renewable energy for the countries in question. While similar analyses were conducted in the past for different regions or for just one type of renewable energy, no such study has been conducted in this scale with this method. Another differentiating feature of the study is that it demonstrates the bidirectional nature of the study not just the unidirectional causality. Policymakers are advised to invest in renewable energy projects and also create frameworks which provide incentives to the private sector for renewable energy production.
\end{abstract}

Keywords: renewable energy; human development; panel data analysis; OECD

\section{Introduction}

Across the globe, renewable energy resources have gained importance recently due to the risk of depleting energy resources and the damage that the resources inflict on the environment. Researchers have recently emphasized renewable energy and conducted studies on the topic [1-5]. In addition to affecting factors such as environment and human health, renewable energy resources could also affect the growth and development of countries.

Energy is the heart of human development, and it increases productivity by accelerating social improvement. It would not be possible to achieve sustainable social and economic development 
goals without ensuring and accessing clean, reliable, and affordable energy. Energy affects the people, communities, and countries directly in terms of economic growth, health, safety, environment, education, and employment [6]. Fossil fuel use is dominant in most economies today and it may be thought of as contributing to economic growth; however, it has been argued that this contribution may be short term only and excessive use of fossil fuel may contribute negatively to growth in the long run [7]. Fossil fuels may also lead to increase in emissions, such as Sulphur dioxide [8]. It is also worthwhile to mention that before the industrial revolution, the only energy available for use was the solar energy stored by crops during the year [9] and the industrial revolution would not be possible without extensive use of fossil fuels. Furthermore, some types of renewable energy may be rather controversial. Biofuels especially have been noted as having a negative effect on food prices by taking up farm lands. Tokgoz et al. [10] cite some research that blame the 2007-2008 food price increases on increased bioethanol use in the US. However other researchers have also shown that long term food price increases are caused in general by increases in crude oil prices, demand-supply relations in agricultural markets and changes in exchange rates, while the production and use of biofuels is a minor factor [11].

Reduction in global energy consumption is vital for sustainable development [3]. Currently, the depletion of accessible energy resources and global warming caused by rapidly increasing emissions indicate two significant energy concerns. Therefore, the ventures on renewable energy have increased, since it is inexhaustible, clean, and safe. It is expected that renewable energy would contribute positively to sustainable development and human development [12].

Recently, renewable energy has been posited as a productive and effective solution to increase energy volume while countering environmental concerns caused by energy. Due to the close relationship between renewable energy and sustainable development, the improvement of renewable energy technologies will contribute to sustainable growth [13]. As a consequence of using more renewable energy sources, environmental pollution will decrease and this will have a positive impact on human health. A healthy generation can play an important role in the development process [14]. The United Nations Development Program declared that clean and reliable energy affected the determinants of human development (education, health, environmental safety, and gender equality) [15].

Ensuring that the energy supply is more affordable, reliable, environmentally friendly, and safer will contribute to sustainable economic development as increased use of renewable energy will reduce greenhouse gases and improve access to energy for the poorest members of society [16]. The use of renewable energy technologies such as wind, solar, hydroelectric, and biomass has increased in recent years because of policies and reduced costs [17]. Both the United Nations Development Program and the World Bank have provided financial support to the projects that aim to improve rural life and to control it remotely by reducing fossil fuel consumption and supporting the private sector in energy production with renewable energy resources [13].

Sustainable development goals published by the United Nations Development Program (decided in 2016) consist of 17 items, one of which is accessible and clean energy. According to the accessible and clean energy goal, a global economy based on fossil fuels and increased greenhouse gas emission causes great changes in the climate system. With the promotion of clean energy, renewable energy has constituted $20 \%$ of global energy since 2011. The subtitle of the goal highlights the need to invest in resources such as wind, solar power, and thermal power to ensure that everyone can access energy by 2030 [18].

Table 1 presents the progress of Renewable Energy and the Human Development Index in 28 OECD countries, which constitute the sample of this study, within the period from 1990 to 2017. The table illustrates that the country with the highest renewable energy level in 1990 is Sweden, followed by Austria; the lowest level was observed in Malta, followed by Cyprus. It should be noted that that both Malta and Cyprus are Island countries whose energy needs are satisfied mostly by single thermal power plants. In 2017, the highest renewable energy level was observed in Latvia, followed by Sweden; the lowest level was observed in Malta, which was followed by the Netherlands. An examination of the percentage change of the renewable energy data between 1990 and 2017 indicates that the highest 
percentage change occurred in Lithuania, followed by the United Kingdom and Estonia; the lowest percentage change occurred in Austria, followed by France.

Table 1. The progress of renewable energy and human development index in 28 OECD countries used in the study (only 1990 and 2017 values are presented in the table).

\begin{tabular}{|c|c|c|c|c|c|c|}
\hline \multirow{2}{*}{ Countries } & \multicolumn{3}{|c|}{ Renewable Energy } & \multicolumn{3}{|c|}{ Human Development Index } \\
\hline & 1990 & 2017 & Percentage Change & 1990 & 2017 & Percentage Change \\
\hline Austria & 20.25 & 29.2 & 45 & 0.795 & 0.912 & 14.71 \\
\hline Belgium & 1 & 7.31 & 600 & 0.806 & 0.917 & 13.77 \\
\hline Czechia & 2.29 & 10.14 & 400 & 0.730 & 0.888 & 21.64 \\
\hline Denmark & 5.94 & 33.77 & 560 & 0.799 & 0.929 & 16.27 \\
\hline Finland & 19.34 & 33.73 & 73.68 & 0.784 & 0.924 & 17.85 \\
\hline France & 6.8 & 9.83 & 50 & 0.780 & 0.890 & 14.10 \\
\hline Germany & 1.51 & 13.38 & 1200 & 0.801 & 0.938 & 17.10 \\
\hline Greece & 5.15 & 11.28 & 120 & 0.753 & 0.871 & 15.67 \\
\hline Hungary & 2.59 & 11.03 & 450 & 0.704 & 0.841 & 19.46 \\
\hline Ireland & 1.69 & 9.67 & 800 & 0.764 & 0.939 & 22.90 \\
\hline Italy & 4.42 & 17.06 & 325 & 0.769 & 0.881 & 14.56 \\
\hline Luxemburg & 0.54 & 7.28 & 1300 & 0.791 & 0.908 & 14.79 \\
\hline The Netherlands & 1.14 & 5.51 & 400 & 0.830 & 0.932 & 12.28 \\
\hline Poland & 1.53 & 8.54 & 700 & 0.712 & 0.868 & 21.91 \\
\hline Portugal & 19.53 & 21.22 & 10.52 & 0.711 & 0.848 & 19.26 \\
\hline Slovakia & 1.54 & 9.15 & 800 & 0.739 & 0.854 & 15.56 \\
\hline Spain & 6.91 & 13.09 & 116.66 & 0.754 & 0.891 & 18.16 \\
\hline Sweden & 24.43 & 39.4 & 62.5 & 0.816 & 0.935 & 14.58 \\
\hline United Kingdom & 0.5 & 9.71 & 1700 & 0.775 & 0.919 & 18.58 \\
\hline Bulgaria & 1.19 & 9.92 & 800 & 0.694 & 0.813 & 17.14 \\
\hline Croatia & 12.69 & 21.65 & 75 & 0.670 & 0.835 & 24.62 \\
\hline Cyprus & 0.45 & 7.5 & 1455 & 0.731 & 0.871 & 19.15 \\
\hline Estonia & 1.96 & 18.61 & 1700 & 0.730 & 0.879 & 20.41 \\
\hline Latvia & 13.25 & 43.96 & 230.76 & 0.698 & 0.849 & 21.63 \\
\hline Lithuania & 1.99 & 20.71 & 1900 & 0.732 & 0.866 & 18.30 \\
\hline Malta & 0 & 4.47 & 400 & 0.744 & 0.883 & 18.68 \\
\hline Romania & 2.55 & 18.18 & 800 & 0.701 & 0.813 & 15.97 \\
\hline Slovenia & 9.12 & 15.62 & 66.66 & 0.829 & 0.899 & 8.44 \\
\hline
\end{tabular}

Source: Renewable energy data were obtained from [19] and human development index data were obtained from [20].

According to the human development index data in Table 1, the highest human development observed in 1990 was in the Netherlands and Slovenia; the lowest value was observed in Croatia and Bulgaria. In 2017, the highest index value was observed in Ireland and Germany; the lowest index value was observed in Bulgaria and Romania (two countries with the same index value). The human development index between 1990 and 2017 indicates that the highest percentage change took place in Croatia and Ireland while the lowest change was experienced in Slovenia and Croatia.

The data presented in the table, in general, indicate that the percentage change was positive and significant due to the recent increasing importance of renewable energy. The issue of renewable energy could change according to the development levels of the countries, and it might vary based on the geographical location and the availability of the energy resources. According to the human development data, the values of the countries were generally similar. During the period from 1990 to 2017, the countries with lower index values made up the difference. This could be attributed to the panel, which consisted of developed countries. On the other hand, the reasons could be the importance of growth and development in the countries, the global fight against poverty, and attempts to increase welfare.

This study uses the panel data analysis method to investigate the relationship between renewable energy and human development in 28 OECD countries in the period from 1990 to 2017. While similar analyses were conducted in the case of Pakistan and five countries of the SAARC region [21] and for 
one type of renewable energy [22], no such study has been conducted in this scale with this method. The paper will proceed as follows: First, the literature on the salient studies on this topic is reviewed. Next, the data and method are explained and the empirical analysis is conducted. In the empirical analysis, information is first given on the methodology, and the test results are interpreted. In the final part, reviews and recommendations are presented, and the study is concluded.

\section{Literature Review}

Various studies in the literature address the relationship between renewable energy and human development. Some of these studies identified a relationship between renewable energy and human development $[12,15,23]$. However, one study also concluded that no relationship exists between renewable energy and human development [24]. According to the literature, many studies address the relationship between energy and human development. While certain studies $[25,26]$ identified a relationship between human development and energy, other studies indicated that this relationship was present for only a short term [3]. The studies are summarized below.

In a study on the relationship between renewable energy and human development, Pîrlogea [15] investigated the role of energy in human development in European Union countries in the period 1997 to 2008 by using the regression analysis method. Consumption of renewable energy was included in the energy variable used in the study. The study concluded that there was a relationship between high levels of energy and human development. In another study, Kazar and Kazar [13] examined the relationship between the production of renewable electricity networks and the Human Development Index as a representation of development in 154 countries by using regression and Granger causality analysis methods. The study focused on two periods, which included the short term between 2005 and 2010 and the long term from 1980 to 2010 (five-year data). Their study concluded that a bidirectional causality relationship existed between renewable energy and development in the short term and that development would lead to renewable energy production in the long term. In a similar study, Satrovic [12] investigated the relationship between human development and renewable energy in Turkey between 1992 and 2015 by using the Johansen cointegration analysis and the Granger causality analysis. The study concluded that there was a unidirectional relationship from renewable energy towards human development. In another study, Wang et al. [24] investigated the relationship between the consumption of renewable energy, economic growth, and human development in Pakistan in the period from 1990 to 2014 through the two-stage least squares (2SLS) analysis. The study indicated that renewable energy consumption did not improve the human development process in Pakistan. According to Lawson [27] human development requires energy even at early stages of development and therefore suggests the Sub-Saharan countries that are the subject of the study to invest in renewable energy sources.

In a study on the relationship between energy and human development, Wu et al. [3] examined the relationship between the transition to energy consumption and human development in 105 countries (in three groups) by using the panel data analysis method. Their study determined that the catch-up elasticity decreased rapidly with the increase in the energy or electricity consumption per person in the early stages of human development in both high-income OECD countries and emerging countries, and then it stabilized; the value of catch-up elasticity between the two groups was different. Furthermore, they stated that, to achieve improved human development, a nation should not rely solely on the increase in the energy or electricity consumption, which would only be valid for the short term. In another study, Ouedraogo [28] investigated the relationship between energy consumption and human development in 15 developing countries in the period from 1988 to 2008 by using the panel cointegration and error correction models. The study determined that a long-term relationship exists between human development and energy consumption. A study by Sanchez-Loor and Zambrano-Monserrate [26] examined the relationship between electricity consumption, GDP, direct foreign capital investments, human development, and remittances in Colombia, Mexico, and Ecuador in the period from 1980 to 
2012 by using the causality analysis method. In one of the results of the study, they found a bidirectional causality relationship between human development and electricity production in Colombia.

As human development could be used in place of concepts such as development and socio-economic development, the literature related to these concepts was also included in the study. In his study, Bello [1] investigated the relationship between renewable energy and socio-economic development in Sub-Saharan African countries. The study determined that renewable energy resources could promote socio-economic activities when used fully and appropriately. In another study, the sustainability of the Spanish development model is evaluated for the period of 1980-2010 using cointegration method. In the model, the relationship between renewable and nonrenewable energy resources and pollution and economic development is investigated. In the study, GDP is used for growth and the human capital and social development index is used for development. The results that are obtained are also compared to France, Germany, Italy, and the United Kingdom. As a conclusion of the study it was observed that renewable energy consumption has a positive impact on growth and development [29]. In another study, Soukiazis et al. [2] investigated the relationship between renewable energy, economic development, and environmental pollution in 28 OECD countries in the period from 2004 to 2015 . They determined that the consumption of renewable energy predicted the sustainable development levels of countries in addition to human and physical capital. In a similar study, Güney [23] examined the effect of renewable and nonrenewable energy on sustainable development in 40 developed and 73 developing countries within the period from 1990 to 2014 by using OLS, System GMM, and 2SLS methods. The study concluded that renewable energy had a positive effect on sustainable development in developed and developing countries.

This research question also drew interest in recent papers from 2019 and 2020. Ergun et al. [30], examined the relationship between renewable energy consumption and social and economic indicators for 21 African countries for the period of 1990-2013 using panel data analysis. As a conclusion, the authors determined that in the countries with high human development index and GDP, renewable energy share is lower. In a recent study [31], four factors-human development, renewable energy, carbon dioxide emissions, and recycling-were analyzed in a structural model. Here, the authors conclude that both renewable energy and recycling contribute to human development of the OECD countries. Mombeuil [32] analyzes the renewable energy levels and human development indicators among other factors for a single country without any econometric methods. Haiti stands out as a country with low HDI levels but very high levels of renewable energy consumption. Another study on a single country investigated energy consumption, economic growth, environmental sustainability, and the human development index in Pakistan from 1990 to 2015 [33]. Here, it was also demonstrated that renewable energy had a positive impact on human development. In another study Khan et al. [34] used information and communication technologies (ICT) and economic growth as a determinant of human development index. As renewable energy is mostly considered a positive factor in human development and environmental health, investment in renewable energies is very complex and often involving multi criteria decision making (MCDM); some MCDM techniques can also be used to guide policy makers when making the renewable investment decisions [35]. In another study involving 17 OECD members during the period 1990-2017, panel data analysis revealed that renewable energy consumption in the long run has a positive impact on sustainable development [36].

\section{Data and Method}

This study aims to see whether more renewable energy use increases the human development level. In order to investigate the relationship between renewable energy use and human development the study focused on the OECD countries and a time span of 27 years. In particular this study investigates the relationship between renewable energy and human development in 28 OECD countries in the period from 1990 to 2017. These countries were selected because the data were continuous in these countries during this time (See Table 1 for countries). Renewable energy data used in the study was obtained from the OECD [19] data resource, and human development index data was obtained from 
the UN [20] resource. In this study, the human development index is taken as the dependent variable, and renewable energy data as the independent variable. Table 2 presents the data used in the study with descriptions.

Table 2. Variables and descriptions.

\begin{tabular}{ccc}
\hline Variable & Abbreviation & Source \\
\hline Human Development Index (Value between 0 and 1) & HDI & {$[20]$} \\
Renewable Energy (Percentage of Energy Production) & RE & {$[19]$} \\
\hline
\end{tabular}

In the study, the relationship between the variables is examined by using the panel data analysis method. First, the cross-sectional dependence relationship is examined among the series; once the cross-sectional dependence is determined, the Pesaran [37] CADF Unit Root Test is administered as it considers this relationship. Next, the cointegration test with structural breaks by Westerlund and Edgerton [38] and panel FMOLS test are performed. Cointegration basically tries to solve the problem of spurious correlation when two time series are both increasing in time, such as foreign direct investment in a country and financial sector development level [39]. In addition, cointegration does not require the assumption that the observed data are stationary with constant mean and variance [25]. Finally, the causality relationship between the variables is investigated. The model used in the study is described below:

$$
\text { Model : } \mathrm{HDI}_{2 \mathrm{it}}=\alpha_{\mathrm{it}}+\beta_{1} \mathrm{RE}_{\mathrm{it}}+\mathrm{u}_{\mathrm{it}}
$$

where $\alpha$ is the fixed term, $i$ is the observation number, $t$ is time, $u$ is the error term, and $\beta_{1}$ is the renewable energy (RE) coefficient prediction.

\section{Empirical Analysis}

The cross-sectional dependence test, the Pesaran [37] CADF (cross-sectionally augmented Dickey-Fuller) unit root test, the Westerlund and Edgerton [38] cointegration test, the panel FMOLS test, Dumitrescu and Hurlin's [40] causality test and Kónya [41] bootstrap causality test results are presented in the subsections that follow.

\subsection{Cross-Sectional Dependence Test}

In the study, the relationship between the series is tested for cross-sectional dependence (i.e., the dependence between human development index and renewable energy). In an empirical analysis, when a cross-sectional relationship exists between the series, performing the analysis without considering this relationship affects the results [42]. When administering the cross-sectional dependence test, the Breusch and Pagan [43] LM test is used, in cases where the time dimension is greater than the cross-sectional dimension [44]. The Pesaran [42] CDLM (Cross Sectional Dependence Lagrange Multiplier) test is administered in cases where the cross-sectional dimension is greater than the time dimension, and the Pesaran [42] CDLM2 test is administered in cases where the cross-sectional and time dimensions are equal. On the other hand, Pesaran et al. [45] developed an LM (bias-adjusted CD Test) that could be used in a heterogeneous panel.

The hypotheses regarding the cross-sectional dependence test are presented below:

Hypothesis $\mathbf{1}\left(\mathbf{H}_{\mathbf{1}}\right)$. There is cross-sectional dependence between HDI and RE.

Hypothesis $\mathbf{2}\left(\mathbf{H}_{\mathbf{2}} \mathbf{)}\right.$. There is no cross-sectional dependence between HDI and RE.

If the probability value obtained after the administration of the cross-sectional dependence test is smaller than 0.05 , the null hypothesis, which indicates that there is no cross-sectional dependence, is rejected [45]. According to the test results displayed in Table 3, the null hypothesis is rejected, and a 
cross-sectional dependence is identified among the series. Hence, the Pesaran [37] CADF Unit Root Test is administered as it considers the cross-sectional relationship.

Table 3. Cross-sectional dependence test.

\begin{tabular}{ccccc}
\hline \multirow{2}{*}{ Cross-Sectional Dependence } & \multicolumn{2}{c}{ HDI } & \multicolumn{2}{c}{ RE } \\
& Statistics & Probability & Statistics & Probability \\
\hline CDLM1 [43] & 8918.696 & 0.0000 & 5750.428 & 0.0000 \\
CDLM2 [42] & 310.6221 & 0.0000 & 195.3933 & 0.0000 \\
CDLM [42] & 94.00906 & 0.0000 & 194.8748 & 0.0000 \\
Bias-Adjusted CD Test & 310.1036 & 0.0000 & 70.41324 & 0.0000 \\
\hline
\end{tabular}

\subsection{Pesaran CADF Unit Root Test}

Pesaran [37] CADF is a second-generation unit root test that takes the presence of cross-sectional dependence into account. The presence of a cross-sectional relationship must be considered because it is realistic to expect the cross-sectional units to affect each other in the event of a shock in the series [37].

The regression equation of the CADF test is as follows [37]:

$$
y_{i t}=\left(1-\phi_{i}\right) \mu_{i}+\phi_{i} y_{i, t-1}+u_{i t}, i=1, \ldots, N ; t=1, \ldots, T \quad u_{i t}=U_{i} f_{t}+\varepsilon_{i t}
$$

Here, $i$ represents observation number, $t$ represents time, $\mu_{i}$ error term, $f_{t}$ the unobserved common effect, and $\varepsilon_{i t}$ individual specific error.

In the Pesaran [37] CADF panel unit root test, results could be obtained for both the cross-section and the panel in general. CADF test statistics could be calculated for each cross-section; and CIPS (cross-sectionally augmented IPS) statistics could be calculated for the panel average. The CADF unit root test could be administered in cases where the time dimension is greater than the cross-sectional dimension or the other way around. The hypotheses regarding the unit root test are as follows [37]:

$$
\begin{gathered}
H_{0}: \beta_{i}=0 \text { (The series are non-stationary) } \\
H_{1}: \beta_{i}<0, i=1,2, \ldots, N_{1}, \beta_{1}=0, i=N_{1}+1, N_{1}+2, \ldots, N \text { (The series are stationary) }
\end{gathered}
$$

where $N$ represents country, $i$ represents observation number and $\beta_{1}$ is the renewable energy (RE) coefficient prediction.

CIPS statistics Equation (5) indicate the average of the panel through the CADF unit root test, which are obtained by calculating the mean value for all cross-sectional units.

$$
\operatorname{CIPS}(\mathrm{N}, \mathrm{T})=\mathrm{t}-\text { bar }=\mathrm{N}^{-1} \sum_{\mathrm{i}=1}^{\mathrm{N}} \mathrm{t}_{\mathrm{i}}(\mathrm{N}, \mathrm{T})
$$

In the model, $\mathrm{t}_{\mathrm{i}}(\mathrm{N}, \mathrm{T})$, represents the Dickey-Fuller statistic of the $y_{i, t-1}$ coefficient in the CADF regression.

According to the results of the panel unit root test (CIPS statistics) as presented in Table 4, series are non-stationary in their levels, and they became stationary I (I) when the first differences were taken. In other words, the null hypothesis of "the series are non-stationary" is rejected. Therefore, there are no obstacles to administering the cointegration test in the study. 
Table 4. CADF unit root test.

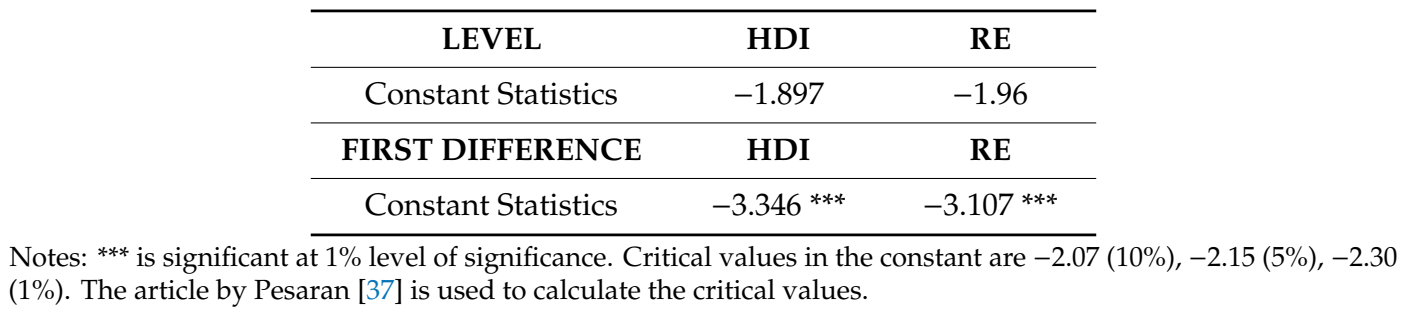

\subsection{Westerlund and Edgerton Cointegration Test with Structural Breaks}

The study uses the Westerlund and Edgerton [38] cointegration test with structural breaks to examine the long-term relationship between the variables. The cointegration test allows breaks in different amounts and dates for each cross-sectional unit and improves the harmonization with the trend function. On the other hand, this test enables further harmonization in more volatile series to obtain better results [38]. Considering the global and economic events experienced in the period from 1990 to 2017 such as the Gulf War, break-up of the Soviet Union, 9/11 attacks, global financial crisis, and the Paris Accord, this test is more appropriate for the study. Table 5 displays the results of the cointegration test.

Table 5. Westerlund and Edgerton [38] cointegration test.

\begin{tabular}{cccc}
\hline Type of Break & Test & Model Statistics & Probability \\
\hline \multirow{2}{*}{ Constant } & tau_n & -3.86825 & 0.08263 \\
& phi_n & -4.59064 & 0.00000 \\
\hline \multirow{2}{*}{ Constant + Trend } & tau_n & -2.92885 & 0.09805 \\
& phi_n & -3.15642 & 0.00080 \\
\hline
\end{tabular}

Notes: Estimated no. of factors $=2.00000$.

Results of the cointegration test are shown in Table 5. The tau_n and phi_n values in the constant and constant + trend in the table indicate that the cointegration relationship is present between the variables used in the study. In other words, the human development index as the dependent variable of the study and the renewable energy as the independent variable act together in the long term.

Dates of structural breaks from the results of the cointegration test are displayed in Table 6. According to the table, the years of 2002, 2008, and 2010 are constant. This could be due to certain reforms in the countries in 2002 (due to the ratification of the Kyoto Protocol by the EU and its Member States, a 2001 referendum in Belgium on giving more electoral power to the regional governments, severance pay reform in Austria and the closing of accession chapters for EU membership of Czechia), the 2008 global crisis, and the 2010 European debt crisis. In the constant and trend results, the year 2014 appeared in addition to the constant model. The economic improvement in Slovenia in 2014 could be the reason for the break.

\subsection{Panel FMOLS Test}

In the study, the panel FMOLS (Fully Modified Ordinary Least Squares) test was used to examine the relationship between the variables. The direction and coefficient of the relationship between the variables is calculated through the FMOLS (least squares) test, which Pedroni [46] introduced to the literature. The panel FMOLS test enables one to correct the deviations that might occur in the standard estimators (autocorrelation, heteroscedasticity, etc.). The results of the Panel FMOLS test are displayed in Table 7. 
Table 6. Dates of structural breaks.

\begin{tabular}{|c|c|c|}
\hline \multirow{2}{*}{ Country } & \multicolumn{2}{|c|}{ Dates of Structural Breaks } \\
\hline & Constant & Constant + Trend \\
\hline Austria & 2002 & 2002 \\
\hline Belgium & 2002 & 2002 \\
\hline Czechia & 2002 & 2002 \\
\hline Denmark & 2010 & 2008 \\
\hline Finland & 2008 & 2008 \\
\hline France & 2008 & 2008 \\
\hline Germany & 2008 & 2008 \\
\hline Greece & 2008 & 2008 \\
\hline Hungary & 2008 & 2008 \\
\hline Ireland & 2008 & 2008 \\
\hline Italy & 2008 & 2008 \\
\hline Luxemburg & 2008 & 2008 \\
\hline The Netherlands & 2008 & 2008 \\
\hline Poland & 2008 & 2008 \\
\hline Portugal & 2008 & 2008 \\
\hline Slovakia & 2008 & 2008 \\
\hline Spain & 2008 & 2008 \\
\hline Sweden & 2008 & 2008 \\
\hline United Kingdom & 2008 & 2008 \\
\hline Bulgaria & 2008 & 2008 \\
\hline Croatia & 2008 & 2008 \\
\hline Cyprus & 2008 & 2008 \\
\hline Estonia & 2008 & 2008 \\
\hline Latvia & 2008 & 2008 \\
\hline Lithuania & 2008 & 2008 \\
\hline Malta & 2008 & 2008 \\
\hline Romania & 2008 & 2008 \\
\hline Slovenia & 2008 & 2014 \\
\hline
\end{tabular}

Table 7. Panel FMOLS test.

\begin{tabular}{cccc}
\hline \multirow{2}{*}{ Variable } & \multicolumn{3}{c}{ Model: $\mathbf{H D I}_{2 \mathrm{it}}=\alpha_{\mathrm{it}}+\boldsymbol{\beta}_{\mathbf{1}} \mathrm{RE}_{\mathrm{it}}+\mathbf{u}_{\mathrm{it}}$} \\
& Coefficient & t-Statistics & Probability \\
\hline $\mathrm{RE}$ & $2.48 \times 10^{-5 *}$ & 1.734391 & 0.0833 \\
\hline \multicolumn{3}{c}{ Notes: ${ }^{*}$ is significant at $10 \%$ level of significance. }
\end{tabular}

According to the results of the FMOLS test, renewable energy affected human development positively and significantly at the significance level of $10 \%$. The results indicate the presence of a cleaner environment due to increased renewable energy resources and improved utilization of the resources and impacts on the human health.

\subsection{Casuality Test Results}

In this research two different types of causality tests have been implemented, namely Kónya [41] and Dumitrescu and Hurlin [40]. The reason for using the two methods is that Kónya [41] provides country-based results, whereas Dumitrescu and Hurlin [40] provides model averages.

\subsubsection{Kónya (2006) Bootstrap Casuality Test}

When compared with other causality methods employed in the literature, the bootstrap technique developed by Kónya [41] is more advanced because it is a regression estimation (seemingly unrelated regression (SUR)) that takes into account cross-sectional dependence. The method not only presents the results of causality, but it also reveals the direction of the relationship. Furthermore, it does not stipulate a common hypothesis for all countries whose bootstrap critical values are based on Wald 
statistics. Finally, the technique has the additional advantage of not requiring the series to be stationary or co-integrated.

The underlying reasoning of the causality test developed by Kónya [41] is the use of the SUR estimators developed by Zellner [47]. The values required for estimation are bootstrap critical values produced in each cross-section. Moreover, the cross-sectional dependence is loosened by the critical estimator, and the causality test can be implemented without a unit root test and cointegration test. SUR estimators are claimed to present more reliable results than OLS estimators. Thus, the panel causality test developed by Kónya [41] was applied to determine causality at the country level. The results of these tests are presented as follows.

Table 8 provides the results on the causality relationship from human development to renewable energy. When the table is examined it is seen that in ten countries (Austria, Belgium, Germany, The Netherlands, Portugal, Slovakia, Spain, Bulgaria, Malta, and Slovenia) there is causality from human development to renewable energy. In the other countries, a causality relationship was not detected. The causality from human development to renewable energy can depend on the level of human development of the countries and their potential to use renewable resources.

Table 8. Kónya (2006) panel bootstrap causality test results (the relationship between human development and renewable energy).

\begin{tabular}{|c|c|c|c|c|}
\hline \multicolumn{5}{|c|}{$\begin{array}{r}\mathrm{H}_{0} \text { : Human Development Is Not the Cause of Renewable Energy. } \\
\text { Bootstrap Critical Value }\end{array}$} \\
\hline Countries & WaldSt. & $1 \%$ & $5 \%$ & $10 \%$ \\
\hline Austria & $15.0013381 *$ & 35.25319 & 19.08871 & 12.97034 \\
\hline Belgium & $21.083064 * *$ & 36.56350 & 19.38923 & 14.24167 \\
\hline Czechia & 2.8337415 & 60.13659 & 36.26669 & 27.08986 \\
\hline Denmark & 2.6975440 & 28.26652 & 15.77132 & 11.03338 \\
\hline Finland & 2.5592910 & 45.24368 & 26.32012 & 19.11744 \\
\hline France & 2.2355268 & 50.44744 & 30.42862 & 22.14002 \\
\hline Germany & 11.299218 * & 23.79716 & 13.57791 & 9.75902 \\
\hline Greece & 5.4107968 & 47.66059 & 26.62590 & 19.92980 \\
\hline Hungary & 12.412319 & 36.47740 & 21.53685 & 15.22435 \\
\hline Ireland & 3.7812713 & 19.34104 & 11.01423 & 7.40838 \\
\hline Italy & 10.329127 & 57.15980 & 34.29410 & 25.61593 \\
\hline Luxemburg & 0.11637456 & 15.06713 & 9.09646 & 6.30460 \\
\hline The Netherlands & 27.503334 * & 63.07358 & 35.10509 & 25.41179 \\
\hline Poland & 2.7191244 & 34.59584 & 19.20772 & 13.60936 \\
\hline Portugal & 9.5297018 * & 22.45138 & 11.82699 & 8.22843 \\
\hline Slovakia & 18.304356 * & 45.00646 & 26.00402 & 18.02931 \\
\hline Spain & 16.794191 * & 33.66661 & 19.66357 & 13.66909 \\
\hline Sweden & 5.3157977 & 30.87343 & 15.56419 & 10.58036 \\
\hline United Kingdom & 2.3356384 & 19.86665 & 10.63897 & 7.36879 \\
\hline Bulgaria & 21.565868 * & 41.55863 & 22.04131 & 14.92944 \\
\hline Croatia & 0.7659643 & 16.44813 & 9.17312 & 6.19477 \\
\hline Cyprus & 10.039882 & 45.34678 & 26.87347 & 19.64749 \\
\hline Estonia & 0.21874470 & 37.63993 & 21.98545 & 15.89987 \\
\hline Latvia & 0.53712939 & 34.35897 & 19.32466 & 13.77155 \\
\hline Lithuania & 2.7325703 & 50.07908 & 28.67004 & 21.14736 \\
\hline Malta & $7.7887826 *$ & 15.58978 & 8.73452 & 5.95794 \\
\hline Romania & 7.1003555 & 34.97384 & 19.05188 & 13.35622 \\
\hline Slovenia & $21.732504 * *$ & 30.39703 & 15.79605 & 10.93223 \\
\hline
\end{tabular}

Note: ${ }^{*}{ }^{* *}$ represent $10 \%$ and $5 \%$ level of significance.

Table 9 provides the results of the causality tests from renewable energy to human development. When the table is examined, this relationship is significant in seven countries (France, The Netherlands, Portugal, Spain, Croatia, Estonia, and Latvia). In addition, there is bidirectional causality for three countries (The Netherlands, Portugal, and Spain). The causality from renewable energy to human 
development can depend on the availability of renewable resources in the country and the potential to use these resources. With renewable energy comes a cleaner environment and improved environmental health, which lead to long term sustainable development.

Table 9. Kónya (2006) panel bootstrap causality test results (the relationship between renewable energy and human development).

\begin{tabular}{|c|c|c|c|c|}
\hline \multicolumn{5}{|c|}{$\begin{array}{r}\mathrm{H}_{0} \text { : Renewable Energy Is Not the Cause of Human Development. } \\
\text { Bootstrap Critical Value }\end{array}$} \\
\hline Countries & WaldSt. & $1 \%$ & $5 \%$ & $10 \%$ \\
\hline Austria & 0.2130645 & 19.69247 & 10.46677 & 7.08682 \\
\hline Belgium & 3.2367066 & 14.65220 & 8.22015 & 5.46605 \\
\hline Czechia & 0.87001155 & 19.48654 & 10.69064 & 7.47911 \\
\hline Denmark & 0.96376042 & 16.59709 & 9.17590 & 6.27237 \\
\hline Finland & 0.18966921 & 22.61397 & 12.06056 & 8.06057 \\
\hline France & 7.5778783 * & 18.45707 & 9.78863 & 6.78456 \\
\hline Germany & 2.5427449 & 16.63735 & 9.07027 & 6.33146 \\
\hline Greece & 3.5938096 & 19.87279 & 10.43047 & 6.91238 \\
\hline Hungary & 3.0943081 & 20.73798 & 10.99431 & 7.37330 \\
\hline Ireland & 0.66049597 & 13.97041 & 8.06029 & 5.60903 \\
\hline Italy & 1.9793152 & 17.58741 & 9.82193 & 6.79547 \\
\hline Luxemburg & 1.0869080 & 19.63854 & 10.30985 & 7.11451 \\
\hline The Netherlands & 9.7456466 * & 18.56357 & 10.47274 & 7.21265 \\
\hline Poland & 0.47501527 & 28.76452 & 15.88730 & 10.77620 \\
\hline Portugal & 9.3787231 * & 22.73549 & 12.23790 & 8.18442 \\
\hline Slovakia & 1.4643561 & 36.45207 & 19.70091 & 13.29230 \\
\hline Spain & $17.624865 * *$ & 18.38115 & 10.13901 & 6.89658 \\
\hline Sweden & 7.1558890 & 26.59170 & 13.72500 & 9.42742 \\
\hline United Kingdom & 1.9951959 & 17.97002 & 9.55147 & 6.37798 \\
\hline Bulgaria & 1.5753305 & 31.79321 & 15.94222 & 10.78297 \\
\hline Croatia & 13.938342 * & 40.11595 & 19.30470 & 13.13473 \\
\hline Cyprus & 1.1392581 & 22.72690 & 12.35363 & 8.20387 \\
\hline Estonia & $188.00279 * * *$ & 48.42957 & 26.80460 & 19.71997 \\
\hline Latvia & $55.949385 * * *$ & 44.30616 & 25.78296 & 18.51995 \\
\hline Lithuania & 4.3286837 & 43.65696 & 24.35220 & 16.99269 \\
\hline Malta & 0.2389288 & 25.39120 & 11.71115 & 7.60458 \\
\hline Romania & 5.6903862 & 49.21803 & 28.38263 & 20.57821 \\
\hline Slovenia & 0.31757501 & 37.00101 & 19.76779 & 14.29413 \\
\hline
\end{tabular}

Note: ${ }^{* * *},{ }^{* * *}$ represent $10 \%, 5 \%$ and $1 \%$ level of significance.

\subsubsection{Dumitrescu and Hurlin Causality Test}

The study applied the panel causality test, which was introduced to the literature by Dumitrescu and Hurlin [40]. This test allows cross-sectional dependency among the countries in the panel. Moreover, it has other advantages such as being applicable when the time dimension is greater than the cross-sectional dimension and in unbalanced panel data sets. Furthermore, the presence of a cointegration relationship does not hinder the administration of the test. The results of the panel causality test are displayed in Table 10.

According to Table 10, a bidirectional causality relationship exists between renewable energy and human development. Examination of the second and third lag lengths indicates a unidirectional causality relationship from renewable energy towards human development. The results demonstrate that the reasons for the relationship from renewable energy resources towards human development could be listed as the availability of a more livable habitat with a clean environment and the impacts on human development as well as its determinants (education, health, income). On the other hand, attributing greater importance to renewable energy (as a result of its development and the renewable 
energy studies conducted by international institutions, particularly the United Nations) could be listed as a reason for the relationship between human development and renewable energy.

Table 10. Results of the panel causality test.

\begin{tabular}{|c|c|c|c|c|c|c|}
\hline \multicolumn{7}{|c|}{ Model: $\mathrm{HDI}_{2 \mathrm{it}}=\alpha_{\mathrm{it}}+\beta_{1} \mathrm{RE}_{\mathrm{it}}+\mathrm{u}_{\mathrm{it}}$} \\
\hline \multirow{2}{*}{ Variables } & \multicolumn{2}{|c|}{$K=1$} & \multicolumn{2}{|c|}{$K=2$} & \multicolumn{2}{|c|}{$K=3$} \\
\hline & $Z_{N}^{H N C}$ & Probability & $Z_{N}^{H N C}$ & Probability & $Z_{N}^{H N C}$ & Probability \\
\hline HDI-RE & 1.71701 & $0.0453^{* *}$ & 1.95957 & 0.5884 & 2.99132 & 0.5264 \\
\hline RE-HDI & 3.03086 & $6 \times 10^{-10 * * *}$ & 6.98789 & $0.0000^{* * *}$ & 10.2357 & $0.0000^{* * *}$ \\
\hline
\end{tabular}

\section{Implications and Limitations}

In this section the theoretical and practical implications will be presented, and the limitations of the research study will be discussed.

\subsection{Theoretical Implications}

When the results of the study are evaluated in the light of the theoretical and empirical literature, it is clear that renewable energy resources affect the economic growth and development of countries. Furthermore, renewable energy resources could positively affect human development in anthropic terms through the socio-economic development of the countries. Therefore, it can be argued that the recent importance attributed to renewable energy could play a role in the development of countries. Hence, renewable energy resources have positive impacts on human health because they are natural, sustainable, and do not damage the environment. Therefore, renewable energy resources are important in terms of achieving a cleaner and more habitable environment, as well as sustainable development.

The most important contribution of this study to theory is that it demonstrates that as countries' renewable energy use increases, so does human development. The effect has been quantitatively proven by novel procedures which take into account many factors and are highly consistent. The finding that renewable energy promotes human development is also consistent with most of the literature reviewed. For example, Bello [1] also states that if properly used renewable energy resources will promote socio economic activities. Using a different quantitative technique, Souikiazis et al. [2] conclude that renewable energy consumption among other factors is an important factor for the sustainable development of countries. Kazar and Kazar [13] have used a similar analysis and report different causality relationships depending on the development level of the countries. This paper reports bidirectional causality, as well for the countries that are at the middle level of human development. Pirlogea [15] uses both fossil fuel and renewable energy as predictors of human development level and also finds a positive coefficient for renewable energy for six countries in question. Güney [23] also demonstrates for 113 countries that renewable energy use contributes more to development than the fossil fuels.

Another unique contribution to the literature of this research is that it demonstrates the structural breaks and the dates of the structural breaks, especially that of 2008, which has not been reported in the previous literature. A country-by-country bootstrap analysis is also a distinctive contribution of the paper.

\subsection{Policy and Social Implications}

When the results of the study are analyzed with respect to policymakers and governmental bodies, it is evident that as the governments invest more in renewable energy sources, they will also increase the human development level. Investing in renewable energy resources may pose certain difficulties for governments including large economic investments. According to Elavarasan et al. [48], among the main causes for the slow development of RE is the lack of proper awareness about it in the general public, 
national and international policies, availability of land for RE plants, political and social awareness, and financial and technical concerns. Therefore, policy makers need motivation for investing in RE projects and the positive relationship with human development may decrease the resistance to renewable energies. Policymakers may also stimulate the private sector for investing in renewable energy projects such as feed-in tariffs (FIT), tax credit and rebates, carbon taxes, renewable portfolio standards, and financing options/loan guarantees for solar or wind investments [49]. There may also be fixed voluntary contributions on energy bills from energy users in order to stimulate renewable energy production [50,51].

\subsection{Limitations and Further Research}

This paper was prepared in the midst of the COVID pandemic. As the pandemic changes, many aspects of social and economic life around the world the results may also change depending on the outcome of this crisis and how countries veer to protect their citizens from the negative side effects of the crisis. Future research may address the new normal order the world faces after the pandemic in relation to the use of renewable energy and human development. The COVID pandemic has already reduced global energy demand and increased the importance of local production and storage capabilities [52]. It is yet uncertain how the events will affect the future of renewable energy. In addition, the pandemic may also influence HDI indicators, such as longevity and GDP [53].

This study has certain limitations. One limitation of the research is that it focuses on countries that are members of the OECD, future research may focus on different geographic areas or countries at different levels of economic development. In addition, different variables and alternate regression models could be used to explore similar relationships. For example, Yumashev et al. [54] use a three-stage regression model (3SLS) and include variables such as human development index, actual energy consumption per capita, renewable energy consumption, human capital, and energy consumption.

\section{Conclusions}

The number of research studies on alternative energy resources has increased recently, due to the risk of energy resource depletion and the damage that fossil fuels inflict on the environment. Natural renewable energy resources, such as wind and solar power, are primary alternative energy resources. The importance of renewable energy sources has increased gradually in recent years because they are sustainable and do not harm the environment.

In addition to their development levels, the geographical locations of the countries could change the distribution of renewable energy resources among countries. These differences in the countries may be attributed to factors such as the amount of sunlight, strength and presence of wind, water resources, and thermal factors. Moreover, the extent to which the renewable energy resources could be utilized based on the development level of the countries should also be taken into consideration. Renewable energy resources are environmentally friendly, and they contribute to a more habitable world, as well as the economic and social development of countries.

This study investigated the relationship between renewable energy and human development in 28 OECD countries in the period from 1990 to 2017 by using the panel data analysis method. First, the cross-sectional dependence test was administered in the study; once a cross-sectional dependence relationship was determined, a second-generation unit root test was administered. The series were determined to be stationary and it was concluded that a cointegration relationship exists between the variables according to the cointegration test results. The results of the FMOLS test determined that the renewable energy affected human development positively and significantly at the significance level of $10 \%$.

In addition, according to the Dumitrescu and Hurlin [40] panel causality results, a bidirectional relationship was observed between renewable energy and human development. The impact of renewable energy on human development was stronger than the reverse. When considering the second and third lags however the relationship was significant from renewable energy to human development 
and the reverse was not true. When countries invest in renewable energies, the environmental quality increases and also the fossil fuels come as imports so there may also be positive economic effects. Due to these effects, the human development index components of education, income, and health all get better, and this can be observed at lags of two and three years as well.

Bootstrap analysis employed in the study also yielded country by country results. The bootstrap analysis indicated that in ten countries (Austria, Belgium, Germany, The Netherlands, Portugal, Slovakia, Spain, Bulgaria, Malta, and Slovenia) there is causality from human development to renewable energy. Furthermore, in seven countries (France, The Netherlands, Portugal, Spain, Croatia, Estonia, and Latvia) there is causality from renewable energy to human development. It is also observed that there is bidirectional causality for three countries (The Netherlands, Portugal, and Spain).

This study demonstrates with a set of robust techniques that renewable energy does not only bring about environmental benefits, but also improves human development measures. Due to the positive relationship between renewable energy production and human development indicators, policymakers should encourage renewable energy projects. Future research may be conducted to include more countries and to study the effect of the pandemic.

Author Contributions: M.U.S., E.S., Y.E.Y., and U.A. contributed equally to all aspects of the research reported in this paper. All authors have read and agreed to the published version of the manuscript.

Funding: This research received no external funding.

Conflicts of Interest: The authors declare no conflict of interest.

\section{References}

1. Bello, M. Renewable energy for sustainable socio-economic development in developing countries: A case study of sub-Saharan Africa. Adv. Mater. Res. 2015, 1116, 33-44. [CrossRef]

2. Soukiazis, E.; Proença, S.; Cerqueira, P.A. The Interconnections between Renewable Energy, Economic Development and Environmental Pollution. A Simultaneous Equation System Approach; Centre for Business and Economics Research (CeBER) Working Paper, No. 10; University of Coimbra: Coimbra, Portugal, 2017; Available online: https:/www.uc.pt/en/uid/ceber/WorkingPapers/wp/wp_2017/wp10 (accessed on 20 January 2020).

3. Wu, Q.; Maslyuk, S.; Clulow, V. Energy Consumption Transition and Human Development (No. 43-10); Monash University, Department of Economics: Melbourne, Australia, 2010. [CrossRef]

4. Sung, B.; Park, S.-D. Who drives the transition to a renewable-energy economy? Multi-actor perspective on social innovation. Sustainability 2018, 10, 448. [CrossRef]

5. He, Z.-X.; Xu, S.-C.; Li, Q.-B.; Zhao, B. Factors That Influence Renewable Energy Technological Innovation in China: A Dynamic Panel Approach. Sustainability 2018, 10, 124. [CrossRef]

6. UNDP. Sustainable Energy and Human Development in Europe and the CIS; United Nations Development Programme: New York, NY, USA, 2014.

7. Zhao, H.; Guo, S.; Zhao, H. Impacts of GDP, fossil fuel energy consumption, energy consumption intensity, and economic structure on $\mathrm{SO}_{2}$ emissions: A multi-variate panel data model analysis on selected Chinese provinces. Sustainability 2018, 10, 657. [CrossRef]

8. Jin, T.; Kim, J. Coal consumption and economic growth: Panel cointegration and causality evidence from OECD and Non-OECD countries. Sustainability 2018, 10, 660. [CrossRef]

9. Wrigley, E.A. Energy and the English industrial revolution. Philos. Trans. R. Soc. A: Math. Phys. Eng. Sci. 2013, 371, 20110568. [CrossRef]

10. Tokgoz, S.; Zhang, W.; Msangi, S.; Bhandary, P. Biofuels and the future of food: Competition and complementarities. Agriculture 2012, 2, 414-435. [CrossRef]

11. Baffes, J.; Dennis, A. Long-Term Drivers of Food Prices, The World Bank, Development Prospects Group \& Poverty Reduction and Economic Management Network, Trade Department; Policy Research Working Paper; The World Bank: Washington, DC, USA, 2013.

12. Satrovic, E. The human development relies on renewable energy: Evidence from Turkey. In Proceedings of the 3rd International Energy \& Engineering, Book of Proceedings, Gaziantep, Turkey, 19-27 October 2018. 
13. Kazar, G.; Kazar, A. The renewable energy production-economic development nexus. Int. J. Energy Econ. Policy 2014, 4, 312-319.

14. Şaşmaz, M.Ü.; Odabaş, H.; Yayla, Y.E. Relationship between health expenditures and development in the OECD countries: Panel data analysis. J. Manag. Econ. 2019, 26, 851-866.

15. Pîrlogea, C. The human development relies on energy. Panel data evidence. Procedia Econ. Finan. 2012, 3, 496-501. [CrossRef]

16. Sathaye, J.; Lucon, O.; Rahman, A.; Christensen, J.; Denton, F.; Fujino, J.; Kadner, S. Renewable energy in the context of sustainable development. In Renewable Energy Sources and Climate Change Mitigation: Special Report of the Intergovernmental Panel on Climate Change; Edenhofer, O., Pichs-Madruga, R., Sokona, Y., Seyboth, K., Kadner, S., Zwickel, T., Eickemeier, P., Hansen, G., Schlömer, S., von Stechnow, C., et al., Eds.; Cambridge University Press: Cambridge, UK, 2011; pp. 707-790. [CrossRef]

17. IRENA. Renewable Energy Benefits: Measuring the Economics; IRENA: Abu Dhabi, UAE, 2016.

18. UNDP Sürdürülebilir Kalkınma Amaçları. UNDP Türkiye. Available online: https://www.tr.undp.org/ content/turkey/tr/home/sustainable-development-goals.html (accessed on 6 March 2020).

19. OECD. Renewable Energy (Indicator). Available online: https://www.oecd-ilibrary.org/energy/renewableenergy/indicator/english_aac7c3f1-en (accessed on 11 January 2020).

20. UN. Human Development Index (HDI). Human Development Data (1990-2017). Available online: http: //hdr.undp.org/en/data (accessed on 11 January 2020).

21. Zahid, T.; Arshed, N.; Munir, M.; Hameed, K. Role of energy consumption preferences on human development: A study of SAARC region. Econ. Chang. Restruct. 2020,1-24. [CrossRef]

22. Wang, Z.; Bui, Q.; Zhang, B. The relationship between biomass energy consumption and human development: Empirical evidence from BRICS countries. Energy 2020, 194, 116906. [CrossRef]

23. Güney, T. Renewable energy, non-renewable energy and sustainable development. Int. J. Sustain. Dev. World Ecol. 2019, 26, 389-397. [CrossRef]

24. Wang, Z.; Danish, Z.B.; Wang, B. Renewable energy consumption, economic growth, and human development index in Pakistan: Evidence form a simultaneous equation model. J. Clean. Prod. 2018, 184, 1081-1090. [CrossRef]

25. Hendry, D.F.; Juselius, K. Explaining cointegration analysis: Part 1. Energy J. 2000, 21, 1-42. [CrossRef]

26. Sanchez-Loor, D.A.; Zambrano-Monserrate, M.A. Causality analysis between electricity consumption, real GDP, foreign direct investment, human development and remittances in Colombia, Ecuador and Mexico. Int. J. Energy Econ. Policy 2015, 5, 746-753.

27. Lawson, L.A. GHG emissions and fossil energy use as consequences of efforts of improving human well-being in Africa. J. Environ. Manag. 2020, 273, 111136. [CrossRef]

28. Ouedraogo, N.S. Energy consumption and human development: Evidence from a panel cointegration and error correction model. Energy 2013, 63, 28-41. [CrossRef]

29. Caraballo Pou, M.A.; Garcia Simon, J.M. Renewable energy and economic development. An analysis for Spain and the biggest European economies. Trimest Econ. 2017, 84, 571-609.

30. Ergun, S.J.; Owusu, P.A.; Rivas, M.F. Determinants of renewable energy consumption in Africa. Environ. Sci. Pollut. Res. 2019, 26, 15390-15405. [CrossRef]

31. Cerqueira, P.A.; Soukiazis, E.; Proença, S. Assessing the linkages between recycling, renewable energy and sustainable development: Evidence from the OECD countries. Environ. Dev. Sustain. 2020, 1-26. [CrossRef]

32. Mombeuil, C. Institutional conditions, sustainable energy, and the UN sustainable development discourse: A focus on Haiti. J. Clean. Prod. 2020, 254, 120153. [CrossRef]

33. Abid, N.; Wu, J.; Ahmad, F.; Draz, M.U.; Chandio, A.A.; Xu, H. Incorporating environmental pollution and human development in the energy-growth nexus: A novel long run investigation for Pakistan. Int. J. Environ. Res. Public Health 2020, 17, 5154. [CrossRef]

34. Khan, N.H.; Ju, Y.; Hassan, S.T. Investigating the determinants of human development index in Pakistan: An empirical analysis. Environ. Sci. Pollut. Res. 2019, 26, 19294-19304. [CrossRef]

35. Zhong, J.; Hu, X.; Yüksel, S.; Dinçer, H.; Ubay, G.G. Analyzing the investments strategies for renewable energies based on multi-criteria decision model. IEEE Access 2020, 8, 118818-118840. [CrossRef]

36. Hassoun, S.E.S.; Ayad, H. Renewable energy and sustainable development: Evidence from 17 OECD countries. Int. J. Econ. Bus. Polit. 2020, 4, 41-60. 
37. Pesaran, M.H. A simple panel unit root test in the presence of cross-section dependence. J. Appl. Econ. 2007, 22, 265-312. [CrossRef]

38. Westerlund, J.; Edgerton, D.L. A simple test for cointegration in dependent panels with structural breaks. Oxf. Bull. Econ. Stat. 2008, 70, 665-704. [CrossRef]

39. Bayar, Y.; Gavriletea, M.D. Foreign Direct Investment Inflows and Financial Development in Central and Eastern European Union Countries: A Panel Cointegration and Causality. Int. J. Financ. Stud. 2018, 6, 55. [CrossRef]

40. Dumitrescu, E.I.; Hurlin, C. Testing for Granger non-causality in heterogeneous panels. Econ. Model. 2012, 29, 1450-1460. [CrossRef]

41. Kónya, L. Exports and growth: Granger causality analysis on OECD countries with a panel data approach. Econ. Model. 2006, 23, 978-992. [CrossRef]

42. Pesaran, M.H. General Diagnostic Tests for Cross Section Dependence in Panels. CESifo Working Paper Series, No. 1229; 2004. Available online: https://www.cesifo.org/DocDL/cesifo1_wp1229.pdf (accessed on 16 January 2020).

43. Breusch, T.S.; Pagan, A.R. The Lagrange multiplier test and its applications to model specification in econometrics. Rev. Econ. Stud. 1980, 47, 239-253. [CrossRef]

44. Baltagi, B.H.; Feng, Q.; Kao, C. A Lagrange multiplier test for cross-sectional dependence in a fixed effects panel data model. J. Econ. 2012, 170, 164-177. [CrossRef]

45. Pesaran, M.H.; Ullah, A.; Yamagata, T. A bias adjusted LM test of error cross section independence. Econ. J. 2008, 11, 105-127. [CrossRef]

46. Pedroni, P. Fully modified OLS for heterogeneous cointegrated panels. Adv. Econ. 2000, 15, 93-130. [CrossRef]

47. Zellner, A. An efficient method of estimating seemingly unrelated regressions and tests for aggregation bias. J. Am. Stat. Assoc. 1962, 57, 348-368. [CrossRef]

48. Elavarasan, R.M.; Shafiullah, G.; Padmanaban, S.; Kumar, N.M.; Annam, A.; Vetrichelvan, A.M.; Holm-Nielsen, J.B. A comprehensive review on renewable energy development, challenges, and policies of leading Indian states with an international perspective. IEEE Access 2020, 8, 74432-74457. [CrossRef]

49. Sener, C.; Fthenakis, V. Energy policy and financing options to achieve solar energy grid penetration targets: Accounting for external costs. Renew. Sustain. Energy. Rev. 2014, 32, 854-868. [CrossRef]

50. Akkucuk, U. Consumer attitudes towards renewable energy: A study in Turkey. In Handbook of Research on Supply Chain Management for Sustainable Development; Akkucuk, U., Ed.; IGI Global: Hershey, PA, USA, 2018; pp. 61-74. [CrossRef]

51. Streikimiene, D.; Mikalauskiene, A. Lithuanian consumer's willingness to pay and feed-In prices for renewable electricity. Amfiteatru Econ. 2014, 16, 594-605.

52. Wang, B.; Yang, Z.; Xuan, J.; Jiao, K. Crises and opportunities in terms of energy and AI technologies during the COVID-19 pandemic. Energy AI 2020, 1, 100013. [CrossRef]

53. Maliszewska, M.; Mattoo, A.; Van Der Mensbrugghe, D. The potential impact of COVID-19 on GDP and trade: A preliminary assessment. World Bank Policy Res. Work. Pap. 2020. [CrossRef]

54. Yumashev, A.; Ślusarczyk, B.; Kondrashev, S.; Mikhaylov, A. Global indicators of sustainable development: Evaluation of the influence of the human development index on consumption and quality of energy. Energies 2020, 13, 2768. [CrossRef]

(C) 2020 by the authors. Licensee MDPI, Basel, Switzerland. This article is an open access article distributed under the terms and conditions of the Creative Commons Attribution (CC BY) license (http://creativecommons.org/licenses/by/4.0/). 